Supplement of Earth Syst. Dynam., 13, 393-418, 2022

https://doi.org/10.5194/esd-13-393-2022-supplement

(C) Author(s) 2022. CC BY 4.0 License.

(c) (1)

Earth System
Dynamics

E़่U

Supplement of

\title{
Spatiotemporal patterns and drivers of terrestrial dissolved organic carbon (DOC) leaching into the European river network
}

Céline Gommet et al.

Correspondence to: Céline Gommet (celine.gommet@ulb.be)

The copyright of individual parts of the supplement might differ from the article licence. 


\section{Supplementary Figures and Tables}

Table S. 1 List of the parameters for the new soil carbon module of ORCHILEAK with their description, value, units, and the parameterization used for each parameter.

\begin{tabular}{|c|c|c|c|c|}
\hline PARAMETER & DESCRIPTION & VALUE & UNIT & PARAMETRIZATION \\
\hline D_DOC & $\begin{array}{l}\text { Molecular diffusion } \\
\text { coefficient of DOC }\end{array}$ & $1.06 * 10^{-5}$ & $m^{2} d^{-1}$ & Ota et al., 2013 \\
\hline \multirow[t]{2}{*}{ D_bio } & $\begin{array}{l}\text { Diffusion coefficient } \\
\text { used for bioturbation }\end{array}$ & $2.74 * 10^{-7}$ & $m^{2} d^{-1}$ & Koven et al. (2013) \\
\hline & litter and soil carbon & & & \\
\hline CUE & $\begin{array}{l}\text { Partitioning between } \\
\text { SOC production and } \\
\text { respiration }\end{array}$ & 0.3 & - & This study \\
\hline$\omega_{\mathrm{L}}$ & $\begin{array}{l}\text { Production of DOC by } \\
\text { the decomposition of } \\
\text { litter }\end{array}$ & 0.2 & $\%$ & This Study \\
\hline$\omega_{\text {soc }}$ & $\begin{array}{l}\text { Production of DOC by } \\
\text { the decomposition of } \\
\text { SOC }\end{array}$ & 1.2 & $\%$ & This study \\
\hline $\mathrm{k}_{\mathrm{D}}$ & $\begin{array}{c}\text { equilibrium partition } \\
\text { coefficient }\end{array}$ & $8.05 * 10^{-5}$ & $\begin{array}{l}\mathrm{m}^{3} \text { water } \\
\mathrm{kg}^{-1} \text { soil }\end{array}$ & Moore et al. (1992) \\
\hline
\end{tabular}




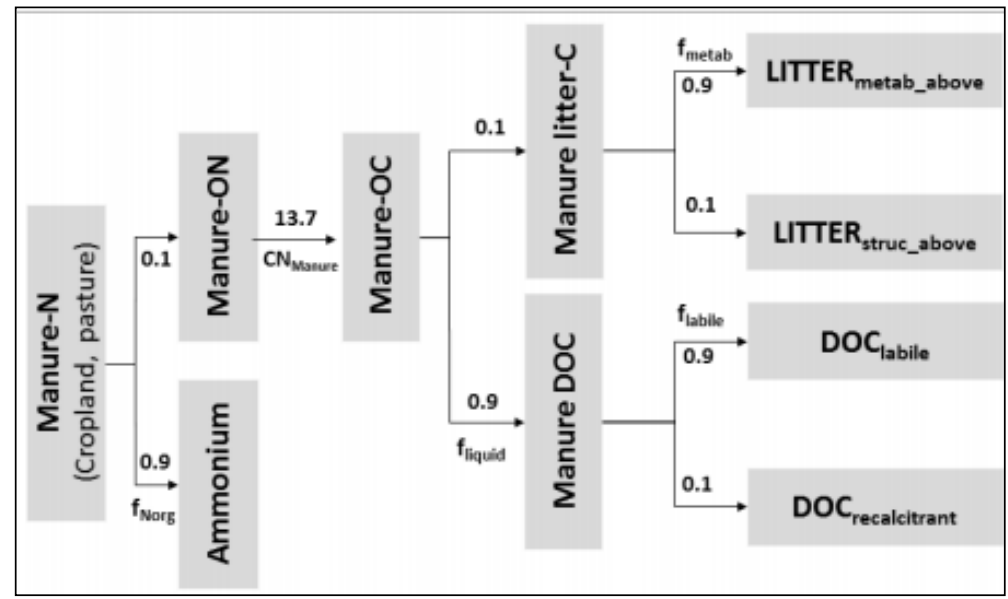

Figure S1. Implementation of the manure scheme in ORCHILEAK.

Table S2. Dominant pfts (\%) for 5 large European river catchments.

\begin{tabular}{lcccc}
\hline \multirow{2}{*}{ BASINS } & $\begin{array}{c}\text { BOREAL FOREST } \\
\text { \% }\end{array}$ & TEMPERATE FOREST \% & $\begin{array}{c}\text { GRASSLAND } \\
\text { CROPLAND }\end{array}$ & $\begin{array}{c}\text { CR } \\
\text { Danube }\end{array}$ \\
\hline Elbe & 27 & 8 & 22 & 39 \\
\hline Rhine & 10 & 6 & 26 & 41 \\
\hline Rhône & 10 & 20 & 35 & 24 \\
\hline Seine & $<0.1$ & 15 & 50 & 18 \\
\hline
\end{tabular}


Table S3. Hydrology results in multiple catchments across Europe. Comparison catchment areas, discharge observed vs modeled and statistics (Nash-Sutcliffe efficiency, mean error and coefficient of determination.

\begin{tabular}{|c|c|c|c|c|c|c|c|c|c|c|}
\hline${ }^{N} \propto$ & $\begin{array}{l}\text { นn } \\
\text { ஸ̊ำ }\end{array}$ & ర్ & 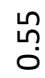 & กొ & $\underset{\stackrel{g}{+}}{\circ}$ & $\stackrel{0}{\circ}$ & $\stackrel{\infty}{\stackrel{\infty}{0}}$ & $\stackrel{\infty}{\circ}$ & 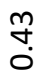 & 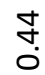 \\
\hline 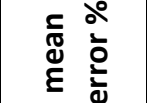 & $\mathscr{\ell}$ & $\underset{\sim}{\sim}$ & $\sim$ & $m$ & ન & $\stackrel{m}{N}$ & $\vec{\neg}$ & ㄱ & $\stackrel{\infty}{\rightarrow}$ & $\stackrel{\infty}{\sim}$ \\
\hline 峛 & $\begin{array}{l}\text { นn } \\
0 \\
0\end{array}$ & 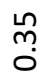 & ثٌ & ¿ & ö & $\stackrel{n}{\longrightarrow}$ & $\stackrel{n}{\stackrel{n}{0}}$ & ¿্. & 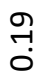 & ô \\
\hline 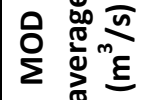 & $\stackrel{\stackrel{n}{m}}{m}$ & $\underset{7}{\stackrel{8}{-}}$ & $\stackrel{\mathcal{F}}{m}$ & $\begin{array}{l}\infty \\
0 \\
0\end{array}$ & $\underset{\sim}{\stackrel{্}{~}}$ & $\underset{⿱}{\stackrel{7}{ت}}$ & $\begin{array}{l}\mathcal{N} \\
\infty\end{array}$ & $\underset{\stackrel{0}{~}}{\stackrel{1}{\sim}}$ & 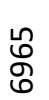 & ర్ల \\
\hline 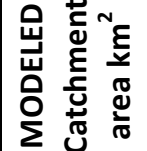 & ষ্ণ & 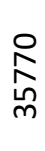 & $\begin{array}{l}D_{1} \\
\infty \\
\qquad \\
y\end{array}$ & 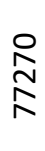 & $\begin{array}{l}\text { D } \\
\infty \\
m \\
\stackrel{m}{\sim}\end{array}$ & $\begin{array}{l}\stackrel{D}{D} \\
\stackrel{\infty}{\stackrel{m}{\sim}}\end{array}$ & 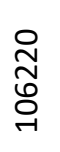 & 昘 & $\begin{array}{l}\infty \\
\infty \\
\stackrel{\rightarrow}{7} \\
\text { مे }\end{array}$ & 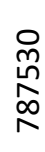 \\
\hline 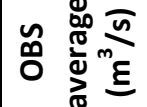 & ్ㅗ & 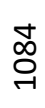 & 品 & 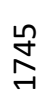 & $\stackrel{\infty}{\stackrel{\infty}{\sim}}$ & ১্ & :ి & 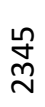 & 永 & $\begin{array}{l}\text { ڤ̊ } \\
\text { fે }\end{array}$ \\
\hline 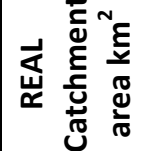 & $\begin{array}{l}\stackrel{8}{0} \\
\stackrel{\sim}{\sim}\end{array}$ & 各 & $\begin{array}{l}8 \\
\stackrel{1}{n} \\
\end{array}$ & $\begin{array}{l}\text { 员 } \\
\text { nू }\end{array}$ & $\begin{array}{l}\stackrel{0}{m} \\
\stackrel{m}{m} \\
\vec{m}\end{array}$ & $\begin{array}{l}\text { 요 } \\
\stackrel{-}{-} \\
\stackrel{m}{\rightarrow}\end{array}$ & $\begin{array}{l}\stackrel{P}{m} \\
\stackrel{-}{O} \\
\underset{ন}{-}\end{array}$ & $\begin{array}{l}8 \\
0 \\
0 \\
0 \\
0 \\
-1\end{array}$ & 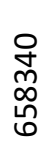 & 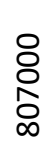 \\
\hline 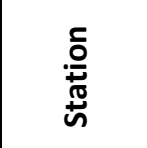 & 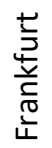 & $\begin{array}{l}\bar{\Phi} \\
\widetilde{\Xi} \\
\infty\end{array}$ & $\begin{array}{l}\frac{\bar{d}}{0} \\
\bar{d} \\
\stackrel{0}{0}\end{array}$ & 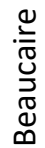 & $\begin{array}{l}\frac{\pi}{2} \\
\frac{\pi}{0} \\
\frac{0}{0} \\
\frac{0}{0} \\
0\end{array}$ & 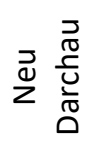 & 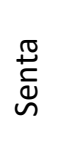 & 产 & 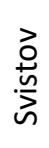 & 胥 \\
\hline
\end{tabular}


Table S4 summarizes the yearly average NPP at the scale of the five selected European catchments. Simulated NPP is of the same order of magnitude as both observation based datasets, without any systematic bias towards an underestimation or overestimation. To provide error bounds for the observational products, we calculated the average standard deviation between yearly-mean values. For GIMMS, we also included the standard deviation induced by the use of the five distinct meteorological forcing files to assess the NPP (section 2.2.1). We find that our simulated catchment averaged NPP fall within the error bounds of the observational products for the Rhine and the Rhone while for the Danube, Elbe and Seine, simulated NPP is slightly above the upper error range.

Table S4 reports the biomass and soil carbon (SOC) stocks for the 5 river basins. SOC stocks are usually slightly overestimated compared to HWSD. Results have also been aggregated the intermediate scale of broad climate zones to analyze how well our model performs for distinct climate regimes. Again the method to calculate the bulk density (section 2.2.2) leads to large uncertainties in observed SOC stocks. Nevertheless, we find that simulated SOC stocks for the warmer climates (Semi-arid and Mediterranean) match well the SOC stocks of the HWSD. However, for other regions, we systematically underestimate the SOC stock compared to HWSD using the Saxton Method, especially in the subarctic climate, but we are closer to the observed values relying on the SOTWIS method for the bulk density. This result is expected since the model does not represent peatlands, which contain important quantities of SOC (Leifeld and Menichetti 2018).

Table S4 Comparison of modeled NPP (1982-2006) against estimates from the CARDAMOM (2001-2010) and GIMMS (1982-2006) datasets. The mean of the two datasets, along with an assessment of the uncertainty (based on MODIS) and of the standard deviation are also reported. In addition, the modeled biomass stock and soil organic carbon (SOC) content (first 1m) are compared with values reported in the HWSD database, using two methods (Saxton and SOTWIS) to calculate the soil bulk density. All variables and processes are reported for the large-scale basins of focus in this study (see fig. 3 for location), the main climate zones of continental Europe and the whole model domain. 


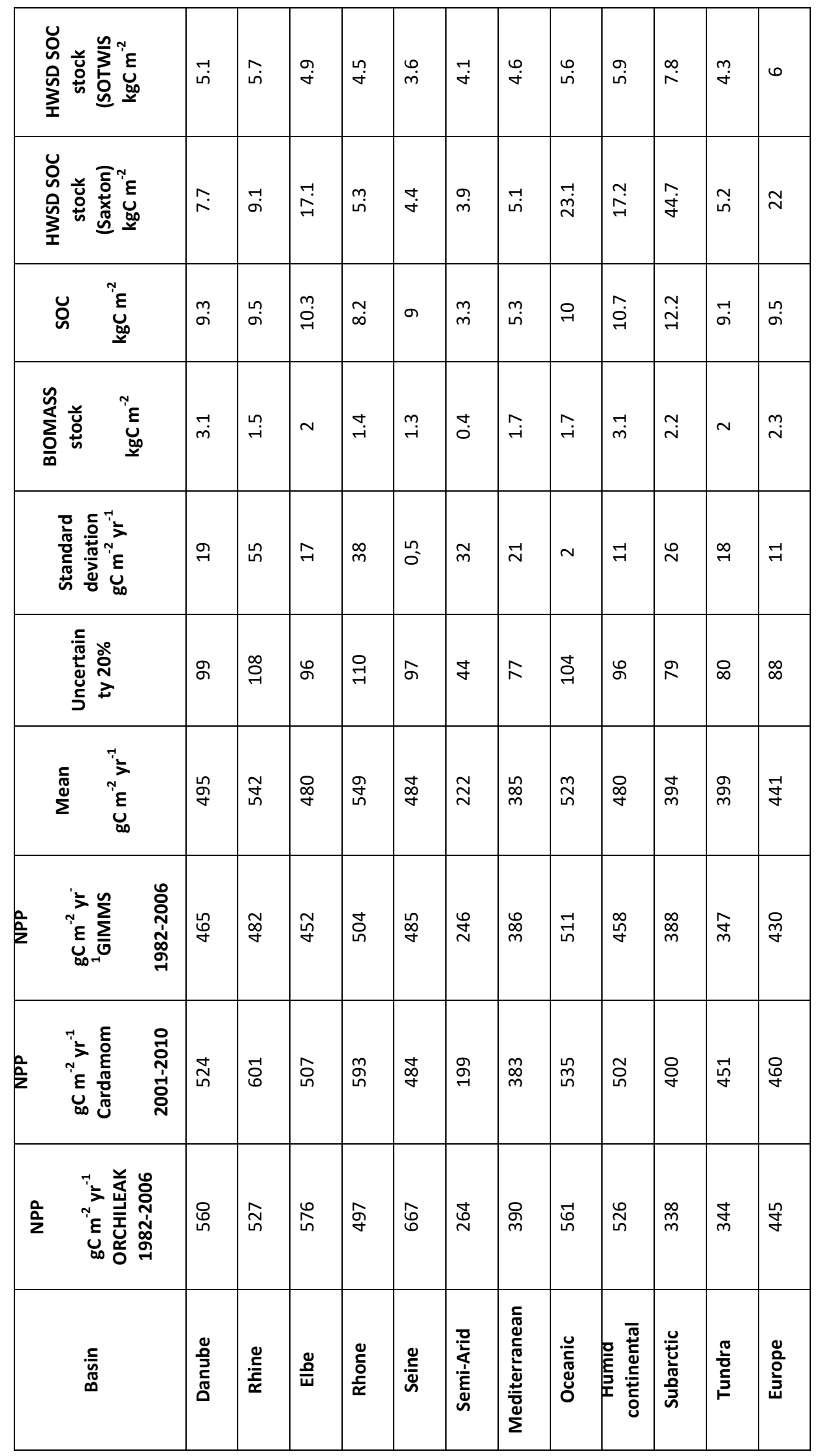


Table S5. Comparison of modeled (MOD) versus observed (OBS) DOC concentrations measured at specific locations along the European river network. The table also reports the location ID (see figure 3), the original reference, and the sampling period.

\begin{tabular}{|c|c|c|c|c|c|}
\hline RIVER & \#ID & SOURCE & COVERED PERIOD & $\begin{array}{c}\text { OBS } \\
\mathrm{mg} \mathrm{Cl}^{-1}\end{array}$ & $\begin{array}{c}\text { MOD } \\
\mathrm{mg} \mathrm{Cl}^{-1}\end{array}$ \\
\hline Douro & A1 & Abril (2002) & 09/1997 & 2.5 & 3.6 \\
\hline Sado & $\mathrm{A} 2$ & Abril (2002) & 04/1996 and 09/1997 & 6.7 & 3.2 \\
\hline Gironde & A3 & Abril (2002) & $11 / 1996$ to $02 / 19998$ & 3.1 & 3.2 \\
\hline Loire & A4 & Abril (2002) & 08/1998 & 3.9 & 4.9 \\
\hline Scheld & A5 & Abril (2002) & $07 / 1996$ to $05 / 1998$ & 6.8 & 7.2 \\
\hline Ems & A6 & Abril (2002) & 07/1997 & 6.8 & 6.4 \\
\hline Elbe & E1 & Abril (2002) & 04/1997 & 4.6 & 6.3 \\
\hline Rhine & Ri1 & Abril (2002) & $10 / 1996$ to $03 / 1998$ & 2.9 & 5.3 \\
\hline Thame & A7 & Abril (2002) & 09/1996 and 02/1999 & 5.8 & 2.5 \\
\hline Tech & M1 & Mattsson (2008) & $10 / 2001$ to $09 / 2002$ & 1.8 & 2.8 \\
\hline Wales & M2 & Mattsson (2008) & $01 / 2002$ to $12 / 2002$ & 5.5 & 2.6 \\
\hline Denmark & M3 & Mattsson (2008) & $10 / 2001$ to $09 / 2002$ & 7.2 & 10.3 \\
\hline Finland & M4 & Mattsson (2008) & $01 / 2001$ to $12 / 2001$ & 13 & 11.1 \\
\hline Rhine & Ri1 & Glorich & 1992 to 1996 & 4.3 & 4.7 \\
\hline Elbe & E1 & Glorich & 1998 to 2001 & 6.1 & 6.2 \\
\hline Seine & S1 & Eau de France & 2002 to 2006 & 6.9 & 4.5 \\
\hline Rhone & Ro1 & Eau de france & 1990 to 1995 & 4.1 & 4.4 \\
\hline England & - & Worrall 2012 & 2001 to 2007 & 4.8 & 7.4 \\
\hline Baltic & - & Fransner 2016 & & 13 & 10 \\
\hline
\end{tabular}


Table S6. Statistics for the simulated discharge, DOC concentration and DOC flux in four large rivers against measured values reported in the GLORICH dataset.

\begin{tabular}{|c|c|c|c|c|c|c|}
\hline RIVER & $\begin{array}{l}\text { DISCHARGE } \\
\text { RMSE \% }\end{array}$ & $\begin{array}{c}\text { DISCHARGE } \\
\mathbf{R}^{2}\end{array}$ & $\begin{array}{c}\text { CONCENTRATION } \\
\text { RMSE \% }\end{array}$ & $\begin{array}{c}\text { CONCENTRATION } \\
\mathbf{R}^{2}\end{array}$ & $\begin{array}{c}\text { FLUX } \\
\text { RMSE \% }\end{array}$ & $\begin{array}{l}\text { FLUX } \\
\mathbf{R}^{2}\end{array}$ \\
\hline Rhine & 45 & 0.43 & 70 & 0.43 & 84 & 0.35 \\
\hline Elbe & 114 & 0.43 & 334 & 0.04 & 121 & 0.5 \\
\hline Rhone & 37 & 0.6 & 117 & 0.1 & 122 & 0.6 \\
\hline Seine & 202 & 0.08 & 64 & 0.4 & 147 & 0.5 \\
\hline
\end{tabular}

